\title{
The convergence and divergence of three pillars of influence in gender and security
}

\author{
'Funmi Olonisakin', Cheryl Hendricks' and Awino Okech ${ }^{3}$
}

\author{
I'Funmi Olonisakin is the Founding Director of the African Leadership Centre, King's College London, UK and a \\ Research Associate in the Department of Political Sciences at the University of Pretoria, South Africa \\ (funmiolonisakin@runbox.com) \\ ${ }^{2}$ Cheryl Hendricks is Head of the Department of Politics at the University of Johannesburg, South Africa \\ (chendricks@uj.ac.za) \\ ${ }^{3}$ Awino Okech is a senior research associate in the Department of Politics at the University of Johannesburg, South \\ Africa (awino.okech@gmail.com)
}

This article explores the convergence between three pillars of influence - feminist security studies, civil society activism and policy decision-making - and its role in the adoption and implementation of United Nations Security Council Resolution (UNSCR) 1325. It argues that these three pillars, individually and collectively, have made important contributions to the debate and action on the gender and security agenda, but that they remain organically disconnected. Their convergence has the potential to achieve path-breaking results in the sphere of gender and security, whilst their divergence makes transformation unattainable. We show the disconnect in the application of UNSCR 1325 in Africa and argue that this is partly the reason why, despite enormous efforts, the gains realised in terms of gender equality in the peace and security arena have been negligible.

Keywords: United Nations Security Council Resolution 1325, gender, feminist security analysis, civil society activism, policy decision-making

\section{Introduction}

Efforts to redress gender inequality remain confined to the periphery of the international security agenda, notwithstanding an evident increase in policy intervention and an active civil society, including academic engagement. Scholarly analysis has continued to offer insights into the drivers of gender inequality and its manifestations in the international security arena. ${ }^{1}$ The adoption of policy frameworks such as United Nations Security Council Resolution (UNSCR) 1325 suggests that there is hope for a qualitative shift in the conditions that sustain gender inequality in regions like Africa, where two decades of armed conflict have created excessive inequalities. However, the absence of meaningful change for women in many corners of the continent after more than a decade of efforts to implement this change, and subsequent resolutions, raises fundamental questions about the relevance and quality of these interventions and actions. 
While there have been many policy instruments and statements from regional and global policy actors alike intended to redress gender inequity, ${ }^{2}$ the question remains as to whether peace- and security-related policy instruments can succeed in transforming gender inequality in Africa. The extent to which the arena of peace and security has drawn attention to gender inequality, but also delivered tangible outcomes, and the role of specific constituencies of actors in this process is the focus of this article. We explore the degree of coherence between the prominent narratives surrounding gender inequality and the approaches to addressing them. To what extent, for example, do the policy frameworks adopted in responding to gender inequality reflect feminist perspectives that propose a transformation in existing structures and power dynamics? Is the commitment and intention of those tasked with implementing these policies aligned with the agenda of gender equality? Or do they perform the role of guardian or gatekeepers to the structures that perpetrate gender inequality, which in turn sustains the cycles of insecurity for women?

This article identifies and discusses three pillars of influence on gender and security - feminist security analysis, civil society activism and policy decision-making. It argues that these three pillars, individually and collectively, have made important contributions to the debate and action on the gender and security agenda, but that they, notwithstanding their apparent interaction, remain organically disconnected. ${ }^{3}$ We argue that their convergence has the potential to achieve path-breaking results while their divergence makes transformation unattainable. We illustrate this with the experiences that led to the adoption of UNSCR 1325 on women, peace and security, and subsequent efforts to implement this resolution in Africa. In this regard, we argue that despite evidence of significant efforts at the policy level, the gains realised in terms of gender equality in the peace and security arena in Africa are negligible.

\section{Three pillars of influence and point of convergence}

Three apparent pillars of influence have driven, in part, the gender and security agenda - globally and regionally. First is the analysis of feminists researching international relations and security studies, which highlights the gendered nature of security. ${ }^{4}$ The second entails the activities of civil society organisations, including women's groups, which have demonstrated a measure of consistency in advocating for gender equality in the post-Cold War period. Typically, these organisations actively engage policy practitioners to promote gender-sensitive policies or their application where such policies are in existence. The third includes a cross-section of policy actors at global, regional and national levels, particularly those with the clout to influence or make policy decisions.

Individually, these pillars have made notable contributions to the gender and security discourse and practice. But their convergence offers the promise of transformation - conceptually and practically - of the terrain on which gender inequality thrives. A convergence of these pillars, for example, led to the adoption of UNSCR 1325, which was path-breaking at the time of its adoption in October 2000. UNSCR 1325 marked the first time that the issue of gender inequality and, in particular, the disproportionate impact of armed conflict on women and their gross under-representation in peace processes, had entered the agenda of the United Nations Security Council (UNSC).

\section{Feminist security analysis}

An examination of the trajectory of feminist security analysis reveals a relatively recent, piecemeal yet multi-layered engagement of feminist analysts with the subject of gender and security. 
Traditional security and strategic studies were not concerned with the experience of individuals and as such it was difficult to highlight the gendered nature of security. Security discourse, particularly in the Cold War era, was state-centric - and understandably so. Analysis responded almost exclusively to the dominant events and narratives of that era. The prevailing realist paradigm concentrated attention on the state and its defence. The defence of the state was in turn viewed within the context of a bipolar world embroiled in a nuclear arms race and the restraining danger of superpower confrontation. Little or no attention was paid to events below the level of the state. As such, the security and safety of individuals had little room in security analysis, let alone any associated issues of gender inequality.

In effect, Africa and the experiences of ordinary Africans were peripheral to this consideration. African states emerged at the heart of the Cold War and inevitably constructed their security and politics to suit the demands of a bipolar world. Immediate post-independent and successive regimes, with very few exceptions, aligned themselves with either side of the Cold War divide. They either leaned toward Soviet-led communist ideology or the Western alliance capitalist stance, even though many of them retained membership of the Non-Aligned Movement. Indeed, while African history and politics were naturally at the core of teaching curriculums and research programmes, international relations (including its strategic studies branch) only emerged as a prominent field of study within African institutions and among African analysts during the 1980s.

The idea that security might be framed to include the personal experiences of individuals - one of the features of feminist theorising - featured little in security studies in Africa. The region had conclusively received a top-down, Anglo-American conception of security. In any case, conceiving of security in state-centric and militaristic ways was well suited to the agenda of regimes that had seized the advantage of a Cold War terrain to entrench themselves in power and adopt narratives that were attractive to their superpower allies. In that dispensation, the character of African states and, in particular, the internal conduct of regimes was far removed from the considerations of their great power allies. The plight of hundreds of millions of citizens who were excluded from access to resources or political participation was far from the radar of the leading powers. Not surprisingly, gender inequality, which was itself a key feature of the entrenched patriarchal structures in these states, was not about to leap to the fore of national and regional attention under those conditions.

To the extent that they engaged in security discourses, feminist analysts responded to the prevailing global security patterns. The role and structure of the institutions dedicated to the defence of the state and to the maintenance of the prevailing international security system provided an obvious channel of engagement. ${ }^{5}$ Scholars such as Cynthia Enloe, V Spike Peterson and J Ann Tickner challenged the partial representations of war proffered by (neo-)realists, contending that they essentially denoted the experiences of men, and 'that International Relations assumptions were grounded in an increasingly unviable assertion of the state as the protector' ${ }^{6}$ In addition, the notion of 'alternative defence' articulated by Booth and Baylis, ${ }^{7}$ among others, was initially peripheral to global security considerations. It, however, provided an avenue and the possibility of bringing to the fore security situations below the level of the state with individuals as a central focus. Hendricks noted:

The work of feminist international relations scholars dovetailed with the general rethinking of security in the post-Cold War context. By 1989, the Soviet Union collapsed and with it the bipolar rivalry that dominated global security discourse for the preceding four decades. Traditional security paradigms were becoming irrelevant in explaining the apparent shift from interstate to intra-state conflicts. The new security paradigm therefore focused on broadening 
the concept of security to include the referents of security (to the individual) and a widening of the range of actors involved in the provision of security. ${ }^{8}$

The outbreak of intra-state conflict was inevitable in Africa, particularly in the absence of the protection offered by superpower clients who courted and supported African governments on the basis of their ideological leanings. 'Rogue' states and leaders had maintained the facade of statehood over the massive insecurities suffered by their people. Scholars and analysts no doubt began to respond to these events. As they did, alternative analyses, which did not gain visibility during the Cold War era and were previously overshadowed by military and strategic studies, began to gain ascendency. ${ }^{9}$ Yet, as Hudson points out, analysis pursued by the 'Copenhagen school', epitomised by Buzan, still drew distinctions between social security where the security concerns of specific groups, such as women, were relegated and international security which dealt with 'collective' security concerns. ${ }^{10}$ This distinction draws attention to the limited ways in which the structural factors that perpetuate gender inequality are understood, and therefore the limited ways in which the pathways to their resolution are defined.

One important school, which featured little in international security considerations during the Cold War, is that of peace studies. The work of Johan Galtung on structural violence and notions of positive and negative peace, ${ }^{11}$ for example, has stood the test of time - but it was far removed from security considerations in strategic studies. Similarly, Kenneth Boulding's analysis of stable peace as an alternative to the unstable peace generated by strategic studies through notions of nuclear deterrence were peripheral to strategic studies and its umbrella discipline of international relations. ${ }^{12}$ With the growing recognition of such seminal works, it became possible to think about peace and security as intertwined agendas - as two sides of the same coin. Perhaps even more significantly for security analysis, critical security theory emerged prominently, challenging the traditional notions of security and strategic studies. It moved away from the idea that the state is the central and perhaps only credible guarantor of security, and challenged realism's reduction of human nature and personal experiences.

Some of the more profound indications of a paradigm shift occurred in cases where analysts that were previously firmly associated with arguments about the correctness and/or supremacy of realist, state-centric thinking in security analysis acknowledged the solid contribution of feminist analysis. The link between theory and the self became acceptable, as opposed to strategic studies, which typically focus on the state and has little room for the perspectives of people: in the words of Booth, 'the personal, the political and the international are a seamless web'. ${ }^{13}$

Although feminist security analysis had already begun to assume a human security tone even before the concept was clearly articulated, it was the conduct of the largely intra-state armed conflicts in places like the former Yugoslavia and several parts of Africa that gave some prominence to feminist security analysis with specific focus on the gendered nature of insecurity not least the disproportionate impact on women.

The armed conflicts witnessed in Liberia (1989-1997) and later in Bosnia (1992-1995), Sierra Leone (1991-2002) and Somalia (1991-present) revealed the character of post-Cold War conflicts. The genocide in Rwanda (1994) was the most extreme manifestation of the conflicts. They were occurring within states, and warring parties freely committed gross atrocities against civilians. The very nature and conduct of these conflicts decidedly shifted attention and, invariably, the security debate to the terrain below the state. It was thus possible to discuss the security of individuals - and within this, that of particular groups of people. By 1994, the concept of human security had made its way to the top of the security discourse, albeit controversially. The notion that the individual ought to be the reference point in security is a central message of the human security concept, 
which gained ascendency from the first time it was elaborated upon in the Human Development Report published by the United Nations Development Programme (UNDP) in $1994 .{ }^{14}$ The idea that individuals must achieve 'freedom from fear and freedom from want' in order to be secure became the central tenets of the human security discourse. The importance of seeing these two freedoms as not mutually exclusive is emphasised by scholars who argue that ensuring economic and social justice is as important as protecting people from violence. ${ }^{15}$

Feminist scholars were quick to point out the limited way in which gender was addressed in the human security discourse, noting that "collapsing femininity or masculinity into the term "human" could conceal the gendered underpinnings of security practices'. ${ }^{16}$ Lewis drew attention to the "formulaic and ad hoc way' in which the human security discourse treated gender, and argued for the need to push the boundaries of the security discourse so that it could meaningfully deal with the insecurity in the domestic sphere. ${ }^{17}$

The subject of gender has not had as visible an impact on or dominated security analysis in the same way as ethnicity and religion, particularly within the context of intra-state conflict (with the exception of, and perhaps reduction to, a focus on rape). While gender may not always be the most important factor if taken as a unit of analysis in security discourse, it does, however, reveal an interconnected web of gendered practices across all levels. ${ }^{18}$ The difficulty associated with gender is that it does not operate alone and interacts with other variables, which mutate at different moments. To manage difference requires resolving all other inequalities - to deal with one alone distorts the reality. The essence of this article's analysis of feminist scholarly engagement with the subject of security is not to explain the engagement, but to show how it influenced and evolved with the then new thinking in security studies.

There are two obvious points on which to rest the discussion of the trajectory of feminist security analysis in Africa. The first is the fact that a significant amount of feminist scholarly work on security is largely generated in the global North. Only a few African feminist scholars have taken this as a direct area of focus. Instead, what we see is a whole range of security analysis that is often rooted in the historical work of what women's movements have accomplished in terms of, for example, violence against women. African scholarship in this area is, however, increasingly stimulated by global militarisation and its impact on the continent and ongoing security sector reform initiatives. Africa's own attempt to offer feminist perspectives to African affairs has produced a small but growing collection of security analysis of direct relevance to Africa. ${ }^{19}$

However, in a continent that had been co-opted into a global security system in which the conduct of regimes and the well-being of the millions of excluded citizens were invisible in the global arena, feminist security analysis, despite its people-centred appeal, remained at a largely conceptual level. As such, while it had a high degree of appeal at least in the academic arena, translating it into robust policy agendas with extensive application did not occur. For any meaningful change to happen, it required that more feminist analysts engage the space of policy and activism. This is further discussed below.

\section{Civil society activism}

The second pillar of influence in gender and security consists of the activities of gender activists, women's groups and non-governmental organisations (NGOs) that have been instrumental in drawing attention to women's insecurity in particular contexts and facilitating relevant action. As will be shown later, the efforts of such activist groups predate the adoption of UNSCR 1325 
and in fact facilitated its coming into being. We now look at the key factors that shaped the activism of this pillar of influence in favour of gender equality.

Campaigns and advocacy for gender equality in the peace and security arena has a pathway that compares with that of feminist security analysis, given that it has also been gradual and responsive to global events and processes. Certain milestones can be identified in the advocacy for gender equality across several decades. Four world conferences on women took place before 2000, in Mexico, Copenhagen, Nairobi and Beijing. It was in Beijing that a clear discussion took place about the insecurity faced by women in situations of armed conflict. Platform E, one of the 12 pillars in the outcome document of that conference, was devoted to the impact of armed conflict on women.

This focus on the impact of armed conflict occurred at the end of the Cold War, when the deadliness of the intra-state conflicts in Liberia, Sierra Leone, Bosnia and Rwanda had become apparent. The significant increase in atrocities against women in these and other armed conflicts produced the level of engagement seen among civil society actors on the issue of violence against women, globally. The advocacy of women's groups in the arena of peace and security grew by accretion, as wars in places like Bosnia and Rwanda wreaked maximum havoc and generated untold atrocities against women across generations. ${ }^{20}$

In the face of these difficult conflicts, efforts intensified in pursuit of the objectives outlined in the outcome document of the 4th World Conference on Women in Beijing in 1995, Platform for Action. ${ }^{21}$ Annual forums such as the Committee on the Status of Women (CSW) became a convening point for strategising on the issues of women affected by armed conflict. It was in one such annual convening of the NGO Caucus on Women and Armed Conflict at the CSW that the idea of placing the issue of women in peace and security processes on the agenda of the UNSC was mooted. ${ }^{22}$ By 1999, there was increased momentum, as a group of NGOs led by International Alert led a global campaign on 'Women Building Peace: From Village Council to the Negotiating Table'. Supported by some United Nations (UN) agencies such as the United Nations Development Fund for Women (UNIFEM), this civil society coalition pushed for the UNSC to take up this agenda. The Windhoek Declaration and Namibia Plan of Action of May 2000 maintained this momentum. It underscored the need to include gender dimensions in peace support operations not least, training, leadership and mission structure. ${ }^{23}$

Women's organisations working in this arena have also been central to supporting peace initiatives where these have emerged. Notable here are the Somali Sixth Clan, Burundi women's contribution to the Arusha talks, Femmes Africa Solidarite (FAS), the Mano River Women's Peace Network (MARWOPNET), Women as Partners for Peace in Africa (WOPPA), the West African Peace Network (WANEP), South African Women in Dialogue (SAWID), and individual women such as Uganda's Betty Bigombe's contributions as a mediator in the protracted talks with the Lords Resistance Army's Joseph Kony. These are just some of the forums through which women's initiatives in mainstream conflict resolution efforts have surfaced. ${ }^{24}$ More importantly, women's rights organisations have continually engaged institutions relevant to the maintenance of just peace such as the police and the judiciary through training and advocacy initiatives aimed at reforming institutional approaches to dealing with women-specific issues.

\section{Policy decision makers and point of convergence}

The third and last pillar of influence includes the action of policy decision makers. Their actions invariably close the intervention cycle in the effort to address the challenge of gender inequality in peace and 
security processes. The policy decisions made by this group of actors make it possible to pave the way toward change. The interdependence of thinking/ideas, policy analysis and action cannot be overstated. The policy aftermath of this interaction is clear evidence of the convergence of these pillars.

Africa, as the continent with the majority of conflict and post-conflict countries, has been a recipient of this combination of efforts, albeit in varying degrees. The second and third pillars of influence in particular have been adapted in various forms in Africa. The African Union (AU), regional economic communities and their respective member states, think tanks, NGOs and women at the community level are engaged with advocating and adopting strategies for gender mainstreaming in peace and security mechanisms.

Africa has been at the receiving end of global policy approaches and peacebuilding interventions for the past two decades. Indeed this could not but be the case given the scale of humanitarian tragedy that began to unfold when a number of African conflicts erupted into violence. These conflict situations challenged global and African institutions alike. In Africa, the Economic Community of West African States (ECOWAS) - a regional organisation founded for reasons of economic integration was the first to break from the straitjacket of normative frameworks such as 'non-intervention in the internal affairs of member states' when it intervened on humanitarian grounds in the Liberian armed conflict. The UN and the Organisation of African Unity (OAU), the AU's predecessor, remained limited by their adherence to this norm for a few years. ECOWAS would later find itself intervening in the conflicts in Sierra Leone, Guinea Bissau and Cote d'Ivoire.

Before long, the agenda of the UN was occupied in large part by a string of African conflicts, although it was also dealing with conflict in other parts of the world, not least the former Yugoslavia and East Timor. Former UN Secretary-General Boutros Boutros-Ghali's Agenda for Peace and its supplement, Another Agenda for Peace, opened the path for expanded frameworks and approaches to peace-making and peacekeeping. This included, among other things, the notions of peacebuilding and post-conflict reconstruction, which were accommodated within multi-dimensional peacekeeping and peace support operations. In due course, the UN would come to deploy peacekeeping and/or observer missions in Somalia, Liberia, Sierra Leone and Rwanda, with varying degrees of effectiveness.

In the period since 2000 we have seen some of the manifestations of sustained action, whether in the form of new policy frameworks or the creation of new entities and institutions to champion the agenda of women in peace and security processes. This was the case when, in October 2000, the issue of women and armed conflict made it onto the agenda of the UNSC with the adoption of UNSCR 1325.

The coalition of civil society (including scholars) and policy actors that worked together to facilitate the adoption of UNSCR 1325 is striking evidence of what can happen when these pillars of influence converge. This was the case, for example, with the governments and ambassadors of Bangladesh, Jamaica, Canada, the Netherlands and the UK, who put their weights behind civil society organisations to champion the cause of women in peace and security processes at the UN in $2000 .{ }^{25}$ This was a key action leading to the adoption of UNSCR 1325 in October 2000; it was clearly the result of the convergence of the analytical work of feminists, the activism of civil society and the weight of policy actors.

\section{UNSCR 1325 and the pathway to application}

The adoption of UNSCR 1325 drew international attention to the linkage between gender and security and the need to include women in the processes of peace-making, peacekeeping and 
peacebuilding. The resolution focuses on a number of issues around the impact of armed conflict on women and their role in conflict management and resolution processes. A core message that runs through the resolution is the need to integrate a gender perspective into peacebuilding and post-conflict reconstruction. The provisions of UNSCR 1325 are typically summed up as 'the 3Ps' - the protection of women, the prevention of armed conflict and the increased participation of women.

Overall, UNSCR 1325 is better conceived of in practical ways - and it is by no means a panacea to the challenges faced by women in peace and security processes. It is the result of a negotiated process - a compromise document that had to find common ground for all signatory states, and not just the states that were enthusiastic about promoting the women, peace and security agenda. As such, it could not meet the expectation that it would go deep enough to address the gender inequalities that are deeply embedded in the discourses surrounding international security institutions and processes, as highlighted by academics and analysts. ${ }^{26}$

Indeed, the compromising nature of UNSCR 1325 might account in part for the thinness of its application on the ground, as discussed below - but it is difficult to draw this conclusion from the patchy data that exists at the moment. On the surface, these three pillars present a picture of a concerted and effective response to the issue of gender inequality. A closer examination, however, reveals that the linkage between them is neither systematic nor deep. Mainstream security discourse, including debates on international security whether at global or regional level, rarely take on board feminist security analysis. Feminist perspectives on gender and security are invariably lost along the way and fail to gain depth in policy approaches and responses. There is no clarity as yet as to where and how the disconnect occurs.

What is apparent, however, is that the policy frameworks developed in response to gender inequality are easily removed from the centre stage of global security concerns. In the same vein, gender activists are easily relegated to the periphery of global and international security considerations, with an emphasis on the humanitarian nature of the challenges facing women, for instance. Gender-related security concerns are only tangentially connected to programmatic interventions designed to implement supposedly new radical international security agendas. Even in the few, typical exceptions such as peace processes, the 'add-on' nature of gender considerations and the superficial inclusion of women remain a regular feature. Similarly, gender concerns are simply added to mainstream security programmatic interventions, as seen, for example, in the areas of security and justice sector reform, post-conflict reconstruction and development.

The value of UNSCR 1325 in exploring this disconnectedness between policy and application is that it offers a prism through which one can view the pathway from analysis to decision-making and practical application. It might then be possible, over time, to systematically investigate this trajectory in order to understand the facilitators and disablers of transformation along this pathway. For now, what is clear is that the obvious convergence of feminist analysis, civil society activism and action by policy decision makers which led to the adoption of UNSCR 1325 has not been a tangible and consistent feature in its application in Africa. The efforts to apply UNSCR 1325 in Africa reveal little or no convergence between these pillars of influence.

\section{The absence of qualitative change}

Efforts to implement UNSCR 1325 are visible at several levels in the region. The first includes UN peace operations in Africa, which often serve as the channel for implementation of UNSCR 1325 
in conflict-affected countries. The logic of the intervening role of peace operations and by extension the UN Department of Peacekeeping Operations (DPKO) in addressing gender inequality is easy to understand. As the leading actor for the restoration of peace in the conflict-affected states, it is the local society's first point of contact with universal norms, principles and policies in the peace implementation process. It is thus the actor best suited to begin the implementation of UNSCR 1325 in those settings. It can do so in a number of ways, including:

- Serving as a model by making its own internal framework and practices reflect the principles of UNSCR 1325;

- Reflecting gender perspectives throughout its programme design and implementation; and

- Reaching out to influence communities and systems in the countries where the UN peace mission is present through its mechanisms and staff, in particular through its gender offices.

Typically, the mandates of peace operations that came into being after the adoption of UNSCR 1325 are now explicit about the implementation of the provisions of the resolution, and UN operations have consistently included gender elements in their periodic reporting. ${ }^{27}$

It is tempting to be self-congratulatory about the attempts to implement UNSCR 1325 within UN operations. Ideally, the concern and attention of policymakers and practitioners as well as a readily interested and energised women's movement should by now be directed to one issue: how best to achieve similar results in the terrains where such peace operations are not present. But thus far, anecdotal evidence suggests that all of the above remain an aspiration rather than a reality. At present there are less than 10 post-conflict environments in Africa where the UN has a peacekeeping presence and where the weight of its institutions and policies can be brought to bear. In those settings, there is no real evidence that gender relations are being transformed or that gender equality is becoming a living reality. ${ }^{28}$

Serious gaps remain in the application of UNSCR 1325 by peace operations. Indeed, peace operations have become a microcosm of the deeper structural issues that serve as obstacles to the achievement of gender equality. The attitudes and values exhibited by many peace operations staff - who do not necessarily believe in or ascribe to gender equality - are part of the problem. As such, many are content to do no more than take a technical approach in dealing with this issue. ${ }^{29}$ This factor appears to be one of the main disablers that prevent transformation in the translation of policies such as UNSCR 1325 into meaningful change in affected societies. Invariably, only the individual Gender Adviser or peace operation staff member with a genuine commitment to the issue of gender equality takes the extra step to go beyond merely 'ticking the box' in implementing gender-related policies.

We must hasten to add that while being potentially the first point of visible and organised UN contact with the organised parts of conflict-affected states and societies, actors connected to the UN DPKO and peace missions are often not the only UN presence on the ground. Apart from their contributions to multi-dimensional peace operations, other UN agencies - including UN Women (formerly UNIFEM), the UNDP, the Food and Agriculture Organisation, the World Food Programme and the United Nations Population Fund (UNFPA) - are often present in conflictaffected societies. While these agencies may interact with local communities in their respective areas of work expertise, opportunities always exist to reflect gender perspectives in their work in conflict-affected areas - and many of them often do. Indeed, agencies like the UNFPA and the UNDP, who are not directly tasked with the application of UNSCR 1325, have taken steps to 
implement UNSCR 1325-related programmes in a number of post-conflict contexts. As earlier indicated, the real challenge lies in the depth and concreteness of the application.

\section{The application of UNSCR 1325 and related agenda by African regional organisations}

The degree to which UNSCR 1325 has been embraced by African states and regional organisations can be reflected in the state of application of regional instruments and of national action plans. In areas without a significant UN presence, which applies to much of Africa, altering the policy and practice of regional actors offers a reasonable chance to influence the performance of its state members. The African Peace and Security Architecture (APSA) presents an ideal framework for implementing UNSCR 1325 and building an overall gender perspective in the work of the African Union Commission (AUC) and in the policies ratified by member states. Given that the Regional Economic Communities (RECs) form one of the 'building blocks' of APSA, implementing UNSCR 1325 and related policy frameworks in the RECs is vitally important for transmitting the values and principles of the resolution.

At the level of the AU, perhaps the most visible manifestation of the internalisation of UNSCR 1325 is the 'Solemn Declaration on Gender Equality in Africa' (SDGEA) of 2004. ${ }^{30}$ This declaration explicitly mentions UNSCR 1325 and confirms the AU's commitment to some issues relating to women, peace and security, including gender-based violence and gender mainstreaming in peace processes. This instrument's articulation of the AU's commitment to the empowerment of women at the highest political levels will need to be matched by a willingness and ability to apply and systematise these principles into the daily life of the organisation.

A number of RECs have also taken steps to address gender-related security issues. Two RECs stand out in this regard - ECOWAS and the Southern African Development Community (SADC). ECOWAS is seeking to address gender and security issues through several platforms, such as the ECOWAS Conflict Prevention Framework (ECPF), which devotes a component to 'women, peace and security', and the development of a Plan of Action for this component. The Directorate of Human Development and Gender is now in the process of implementing this Plan of Action over a three-year period from 2013-2016. ${ }^{31}$ SADC too has taken important steps toward addressing women, peace and security issues, including the SADC Protocol on Gender and Development of 2008, in which Article 28 calls for the implementation of UNSCR 1325, and the SADC gender policy which calls for the eradication of sexual and gender-based violence and all other forms of violence towards women and girls. These instruments have provided opportunities for SADC and its member states to apply the principles of UNSCR 1325.

Notwithstanding these developments at the level of the AU, and within RECs such as ECOWAS and SADC, there is still much to be done within these organisations. For example, women are far from the 50\% mark for representation within the peace and security institutions and programmes of these organisations. The AUC has achieved better results in the appointment of women into senior leadership positions at the level of commissioner and directors, where there is near gender parity, but the organs and associated institutions have not fared as well as the top decision-making structures of the AU - the Heads of State Summit remains an overwhelmingly male sphere. ${ }^{32}$ The AU has now also appointed Bineta Diop as the Special Envoy on Women Peace and Security and deploys gender advisors to its missions. However, just as the AU has been reluctant to shift to multi-dimensional 
peacekeeping, so too has there been no systematic shift in its approach to gender mainstreaming in its peace and security endeavours. Only time will tell whether the presence of the few formidable women now at the AU will be sufficient to create the necessary behavioural shift at the $\mathrm{AU}$ and its associated peace and security organs.

There have been a few AU peacekeeping and political missions in, for example, Burundi, Comoros, Sudan and Somalia. The AU Mission in Somalia (AMISOM) marks the first time there was a visible incorporation of gender considerations into an AU operation through the establishment of the position of a Gender Officer. The role of this officer is to ensure 'that matters of gender are mainstreamed in AMISOM policies and to follow up with the Somalia authorities and other actors to ensure gender mainstreaming in key policy decisions and undertakings' ${ }^{33}$ This was replicated in the African Mission in Mali (AFISMA), but there has been little analysis of the impact of these efforts.

In southern Africa, with its history of liberation struggles, women's participation in the security sector predate UNSCR 1325. The region showed promise that it might lead the way in the achievement of gender equality and provide lessons for the rest of the continent. However, though it has done relatively well in terms of women's representation, the security institutions have not sufficiently grappled with the thorny issues of whose security matters, how it should be provided and what needs to be done differently to ensure greater levels of security for all. That is, the gendered nature of norms, culture and security practices are seldom under scrutiny: UNSCR 1325 was never intended to engage that debate. ${ }^{34}$

\section{Application of UNSCR 1325 at the national level}

The effort to apply UNSCR 1325 transcends UN DPKO, UN agencies and regional institutions. By 2004, proposals for implementing UNSCR 1325 were being put forward. For example, in his report to the UNSC in 2004 on the agenda of women, peace and security, the UN SecretaryGeneral proposed that member states take steps to implement UNSCR 1325 at the national level. ${ }^{35}$ Gradually, the development of National Action Plans (NAPs) on UNSCR 1325 became a regular part of the agenda of a number of member states. National-level implementation has tended to focus on three areas: the participation of women in peace and security decisionmaking processes, the protection of women and girls, and gender training.

Currently 50 countries have approved NAPs on women, peace and security, 15 of which are African countries. It is instructive that African countries with approved NAPs are predominantly those that have experienced significant armed conflict in all or parts of their states.

While 'twinning' with donor country teams may have facilitated the war-affected countries' development of NAPs, the processes of developing these plans in the African countries concerned have been, by and large, 'inclusive' and have looked at women, peace and security issues in a 'holistic' way. ${ }^{36}$ Post-conflict contexts in which peacebuilding is actively undertaken still remain the best opportunity to include gender issues in ways that are not possible in countries that have not experienced open armed conflict.

However, even with these few African countries with NAPs, it is difficult to observe real transformation in the key areas that form the focus of NAPs. Perhaps one exception is Rwanda, although the progress realised in the high numbers of women represented in governance institutions and processes is rooted in a range of affirmative-action policies adopted by the new post-genocide government. However, when the high representation of women in the 
Rwandan Parliament is put to the test across all security-related areas in Rwanda, this trend is not sustained. Careful research is, however, required to see the extent to which this is the case.

Overall, across these countries, the contents of the NAPs varies significantly and there is no clarity about how to measure progress in the absence of monitoring frameworks or indicators. However, it may very well be that UNSCR 1889 (2009), which calls for better data collection and reporting, could be used for this purpose. In sum, there is no real pattern the national level which indicates a qualitative shift towards the introduction of gender perspectives in peace and security matters and processes. The expectation that regional actors and member states will be able to make a positive change in the practice of institutions and society is far from being fulfilled.

\section{Conclusion}

This paper has highlighted that the adoption of UNSCR 1325 on women, peace and security was enabled by the point of convergence of three pillars - feminist security analysis, civil society activism, and policy decision-making. These pillars, it argues, when working in harmony are able to bring about meaningful change in gender equality. However, they are often disconnected and this enables gender to be reduced to an 'add-on' in much of the peace and security discourse and/or to be marginalised in global security concerns. Moreover, in the application of UNSCR 1325 in Africa there has been little convergence between these pillars of influence.

The absence of a cohesive narrative that moves Africa towards the transformation of gender relations in peace and security processes therefore remains glaring. UN interventions are simply taken as part of a general process of peacebuilding; they do not often transform relationships and institutions in-country toward gender equality. Regional organisations and national governments have also not demonstrated an adequate commitment to a qualitative shift in gender inequality on the ground.

The three pillars of influence discussed in this article, at least in part, offer some promise and potential to qualitatively shift the continent toward the agenda of gender equality; but only if they genuinely converge. The recipe for convergence appears reachable but the disabling factors are seemingly entrenched and will require careful dismantling if the desired change is to be realised. As the adoption of UNSCR 1325 has demonstrated, a critical factor in the convergence of these pillars was that all three actors maintained an activist stance. Academics were numbered in the coalition for UNSCR 1325, as were key policy actors.

Ultimately, activism is the common denominator that provides much-needed momentum towards change. When the three pillars are pitched against each other and there is no unity of purpose, achieving impact-making change becomes a challenge. In addition to growing scholarship on gender and security in Africa, it is clear that academics must engage in measured activism, as must policy practitioners with the right credentials to influence change. This has emerged as an important factor in both policy development and application. These ingredients are a necessary driving force behind a change-making movement for gender equality in Africa and elsewhere.

\section{Notes}

1 See, for example, C Enloe, The morning after: sexual politics at the end of the Cold War, Berkeley, CA: University of California Press, 1993; JA Tickner, Gender in international relations: feminist perspectives in achieving global security, New York, 
NY: Columbia University Press, 1992; JA Tickner, You just don't understand: troubled engagement between feminists and IR theorists, International Studies Quarterly, 41, 1997.

2 Falling into this category, for example, are the Convention on the Elimination of All Forms of Discrimination Against Women (CEDAW) and the Beijing Platform for Action, both of which predate the first UNSC Resolution (1325) to deal with unequal security for women as well as gender inequality in peace and security related processes.

3 These three pillars were first identified in an article by two of the authors of the present article; see 'F Olonisakin and C Hendricks, Engaging (in)security as an entry point for seeking redress in gender inequality in Africa, Africa Peace and Conflict Journal, 6, 2013.

4 See, for example, C Enloe, The morning after: sexual politics at the end of the Cold War, Berkeley, CA: University of California Press, 1993; JA Tickner, Gender in international relations: feminist perspectives in achieving global security, New York, NY: Columbia University Press, 1992; JA Tickner, You just don't understand: troubled engagement between feminists and IR theorists, International Studies Quarterly, 41, 1997; I Skjelbaek, Gendered battlefields: a gender analysis of peace and conflict, PRIO Report 6/97, Oslo: International Peace Research Institute 1997; EM Blanchard, Gender, international relations and the development of feminist security theory: a review essay, Signs: Journal of Women in Culture and Society, 28, 2001.

5 See, for example, MW Segal, Women's military roles cross-nationally: past, present and future, Gender and Society, 9 , 1995; C Cockburn and D Zarkov (eds.), The postwar moment: militaries, masculinities and international peacekeeping Bosnia and the Netherlands, London: Lawrence and Wishart, 2002.

6 See CM Hendricks, Gender and security in Africa, Discussion Paper 63, Uppsala: Nordic Africa Institute, 2011, 5. See also $\mathrm{C}$ Enloe, Bananas, beaches and bases: making feminist sense of international politics, Berkeley, CA: University of California Press, 1989; C Enloe, All the men are in the militias, all the women are victims, in LA Lorentzen and J Turpin (eds.), The women and war reader, New York, NY: New York University Press, 1998; V Peterson (ed.), Gendered states: feminist (re)visions on international relations theory, Boulder, CO: Lynne Rienner, 1992; JA Tickner, Gender in international relations: feminist perspectives in achieving global security, New York, NY: Columbia University Press, 1992.

7 K Booth and J Baylis, Britain, N.A.T.O and nuclear weapons: alternative defence versus alliance reform, London: Palgrave Macmillan, 1989.

8 CM Hendricks, Gender and security in Africa, Discussion Paper 63, Uppsala: Nordic Africa Institute, 2011, 6.

9 See, for example, B Buzan, People, states and fear: an agenda for international security studies in the post-Cold War era, Boulder, CO: Lynne Rienner, 1991.

10 H Hudson, Doing security as though humans matter: a feminist perspective on gender and the politics of human security, Security Dialogue, 36, 2005.

11 Among many of his publications, see J Galtung, Essays in peace research, New Jersey: Humanities Press, 1975.

12 KE Boulding, Stable peace, Austin: University of Texas Press, 1978.

13 K Booth, Security and self: reflections of a fallen realist, YCISS Occasional Paper No. 26, York Centre for International and Strategic Studies, 1994.

14 United Nations Development Programme, Human development report, New York: Oxford University Press, 1994.

15 See, for example, M Nuruzzaman, Paradigms in conflict: the contested claims of human security, critical theory and feminism, Cooperation and Conflict, 41, 2006.

$16 \mathrm{H}$ Hudson, Doing security as though humans matter: a feminist perspective on gender and the politics of human security, Security Dialogue, 36, 2005, 157.

17 D Lewis, Rethinking human security: the implications for gender mainstreaming, in C Hendricks (ed.), From state security to human security in southern Africa: policy research and capacity building challenges, ISS Monograph 122, Pretoria: Institute for Security Studies, 2006, 9.

18 H Hudson, Doing security as though humans matter: a feminist perspective on gender and the politics of human security, Security Dialogue, 36, 2005.

19 See, for example, special issue on Militarism, Conflict and Women's Activism in Feminist Africa Issue 10 2008; 'F Olonisakin and A Okech (eds.), Women and security governance in Africa, Oxford: Pambazuka Press, 2011.

20 See 'F Olonisakin and C Hendricks, Engaging (in)security as an entry point for seeking redress in gender inequality in Africa, Africa Peace and Conflict Journal, 6, 2013.

21 See K Barnes, The evolution and implementation of UNSCR 1325: an overview, in 'F Olonisakin, K Barnes, and E Ikpe (eds.), Women, peace and security: translating policy into practice, London: Routledge, 2011.

22 C Cohn, Mainstreaming gender in UN security policy: a path to political transformation?, in SM Rai and G Waylen (eds.), Global governance: feminist perspectives, Basingstoke: Palgrave Macmillan, 2008. 
23 The United Nations Transitional Assistance Group, The Windhoek Declaration and Namibia Plan of Action, 2000, http://www.un.org/womenwatch/osagi/wps/windhoek_declaration.pdf (accessed March 2013).

24 See C Hendricks, Framing the issues, in C Hendricks and M Chivasa (eds.), ISS Women and Peacebuilding Workshop report, Institute for Security Studies, Pretoria, 2009, 10.

25 F Hill, C Cohn, and C Enloe, UN Security Council Resolution 1325 three years on: gender, security and organizational change, Boston Centre for Gender in Organisations, Simmons School of Management, Consortium Lecture January 20, 2004.

26 See K Barnes, The evolution and implementation of UNSCR 1325: an overview, in 'F Olonisakin, K Barnes, and E Ikpe (eds.), Women, peace and security: translating policy into practice, London: Routledge, 2011, 19-20. See also C Cohn, Mainstreaming gender in UN security policy: a path to political transformation?, in SM Rai and G Waylen (eds.), Global governance: feminist perspectives, Basingstoke: Palgrave Macmillan, 2008.

27 Nearly all UN peace operations since the early 2000s have included the implementation of UNSCR 1325 in their mandates in one form or another. In Africa, this currently includes the UN Mission in Liberia (UNMIL), the UN Mission in Sudan (UNMIS), the UN AU Mission in Dafur (UNAMID), the UN Mission in the Congo (MONUC), and the UN Operation in Cote d'Ivoire (UNOCI).

28 See, for example, EN Wamai, UNSCR 1325 implementation in Liberia: dilemmas and challenges, in in 'F Olonisakin, K Barnes, and E Ikpe (eds.), Women, peace and security: translating policy into practice, London: Routledge, 2011; G EltahirEltom, The impact of UNSCR 1325 and peacekeeping operations in Sudan, in 'F Olonisakin, K Barnes, and E Ikpe (eds.), Women, peace and security: translating policy into practice, London: Routledge, 2011.

29 This view is based on observations made on various peace operations. Between them, the authors have conducted field visits in the last decade to conflict-affected and/or peace operations environments in Liberia, Sierra Leone, the Democratic Republic of Congo, Sudan and Somalia.

30 African Union, Solemn Declaration on Gender Equality, Addis Ababa, 2004.

31 Discussion with ECOWAS officials in Abuja at the ECOWAS Partners' Meeting, April 2013

32 R Musa, Evaluation of the implementation of the Solemn Declaration on Gender Equality in Africa, Senegal: Gender in My Agenda Campaign/ Femmes Africa Solidarite, 2009.

33 Interview conducted with AMISOM officials by 'F Olonisakin, Mogadishu, 2 May 2013.

34 See Chapter 8 on Conflict Resolution and Peace Building in the annual editions (2010-2015) of C Lowe Morna, S Dube and L Makamure (eds.) SADC Gender Protocol Barometer, Johannesburg: Gender Links. The chapter is compiled by $\mathrm{C}$ Hendricks in the various annual editions of the SADC Gender Protocol Barometer.

35 United Nations, Report of the Secretary-General on Women, Peace and Security, S/2004/814, New York, 2004.

36 K Barnes, The evolution and implementation of UNSCR 1325: an overview, in 'F Olonisakin, K Barnes, and E Ikpe (eds.), Women, peace and security: translating policy into practice, London: Routledge, 2011, 26. 